\title{
Grazing with heifers and sows alone or mixed: herbage quality, sward structure and animal weight gain
}

\author{
Jakob Sehested $^{\mathrm{a}, *}$, Karen Søegaard ${ }^{\mathrm{b}}$, Viggo Danielsen ${ }^{\mathrm{a}}$, \\ Allan Roepstorff ${ }^{\mathrm{c}}$, Jesper Monrad ${ }^{\mathrm{c}}$ \\ ${ }^{a}$ Department of Animal Nutrition and Physiology, Research Centre Folum, Danish Institute of Agricultural Sciences, P.O. Box 50, \\ DK-8830 Tjele, Denmark \\ ${ }^{\mathrm{b}}$ Department of Crop Physiology and Soil Science, Danish Institute of Agricultural Sciences, P.O. Box 50, DK-8830 Tjele, Denmark \\ ${ }^{\mathrm{c}}$ Danish Centre for Experimental Parasitology, Royal Veterinary and Agricultural University, Ridebanevej 3, \\ DK-1870 Frederiksberg C, Denmark
}

Received 23 April 2003; received in revised form 7 November 2003; accepted 25 November 2003

\begin{abstract}
The aim of the present study was to compare the effect of mixed grazing (MI) by sows and heifers with alternate grazing (AL) or grazing heifers $(\mathrm{HN})$ and sows $(\mathrm{SN})$ alone on animal weight gain, sward structure, herbage quality and composition, and selection during grazing. Mixed or alternate grazing consistently improved the weight gain in both heifers and sows, compared with grazing one species alone, but the positive effect was statistically significant only for heifers. The herbage quality of the MI and AL systems was better compared with the SN system, but not clearly better compared with the HN system. The total animal weight gain (heifers + sows) and estimated herbage intake per hectare were also higher in the MI and AL systems compared with SN and HN systems. The sows grazed selectively as they preferred clover rather than grass and grass leaves rather than grass stem. Only few turnovers of the sward by the sows were observed. Animal behaviour was not systematically surveyed, but no adverse behaviour was observed between the two animal species. Herbage quality, proportion of rejected herbage and the load of gastro-intestinal nematodes in heifers could have positively influenced animal weight gain per day and hectare in the MI and AL systems in this study.
\end{abstract}

(C) 2004 Elsevier B.V. All rights reserved.

Keywords: Pasture; Mixed grazing; Alternate grazing; Sow; Heifer; Sward structure; Organic farming

\section{Introduction}

The number of sows in outdoor production systems has increased in Europe during the past decade (Larsen, 2000), especially in organic farming systems

* Corresponding author. Tel.: +45-8-999-1384; fax: +45-8-9991378 .

E-mail address: jakob.sehested@agrsci.dk (J. Sehested). due to EU-legislation demanding access to grazing for organic sows (EU, 1999). Efficient use of the pasture as a feed source and for utilisation of nutrients from the deposited manure are important in the organic systems, but grazing systems for sows are sparsely documented in the scientific literature. However, it is clear that sows have a significant potential for grazing and utilisation of grass (Fernández et al., 1986; Vestergaard et al., 1995; Sehested et al., 1999; Rivera 
Ferre et al., 2001). In pregnant sows, the intake capacity is high, and it has been shown that pregnant sows are able to obtain about half of their energy requirement from grazing (Sehested et al., 1999; Rivera Ferre et al., 2001) depending on the pasture quality. To obtain efficient grazing and nutrient utilisation, the grass cover has to be kept intact. Ogel (1997) showed that low stocking rate, ringing of sows and supplementary paddocks are important factors for the maintenance of the grass cover. Watson and Edwards (1997) observed, that unrung sows reduced vegetation cover to $10 \%$ within a month.

It is well known that cattle avoid grass close to dung pats, and thereby cause the rejected grass area around dung pats to increase during the season (Søegaard et al., 2001). Nolan and Connolly (1988); Fatyga (1989); Mahieu et al. (1997) reported an improved utilisation of the pasture by mixed grazing of cattle and sheep, because the sheep grazed the grass around cattle dung pats. A number of studies have been published on mixed or alternate grazing with cattle, sheep, goats, horses, camels, and donkeys, usually two species mixed in the same paddock or alternately grazing the same paddocks (e.g. Nari et al., 1987; Quintana et al., 1987; Jordan et al., 1988; Nolan and Connolly, 1988; Schwarz et al., 1988; Sall et al., 1993; Chroust et al., 1998; Troxler, 1998). For both systems increased weight gain per unit of land, reduced parasite load and increased utilisation of the pasture were reported compared with grazing one species alone. However, there seemed to be interactions between grazing system (mixed or alternate), animal species/groups and stocking rates, and environmental conditions on weight gain and parasite load (e.g. Fatyga, 1989; Jordan et al., 1988).

The aim of the present study was to compare mixed grazing by pregnant sows and heifers with alternate grazing or grazing each species alone. The response parameters were animal weight gain and gastro-intestinal nematode load, rejected grass area, herbage quality and composition, and selection during grazing. Data on selection during grazing has been published separately (Nissen, 2000), and so will data on effects on gastro-intestinal nematodes (Roepstorff et al., in preparation). It was our hypothesis that mixed and/or alternate grazing with pregnant sows and heifers would improve herbage quality, vegetation cover and sow weight gain compared with grazing sows alone, and reduce rejected grass area and improve heifers' weight gain compared with grazing heifers alone. To our knowledge there are no other published results of mixed grazing with cattle and pigs, apart from preliminary results from the present study (Roepstorff et al., 2000; Sehested et al., 2000; Søegaard et al., 2000).

\section{Materials and methods}

A pilot Trial was performed in 1997 and continued as an experiment in 1998 (Trial 1). In 1999 a new experiment was established (Trial 2). All trials were carried out during the grazing season (May-October) on a clay soil with $18 \%$ clay and $1.2 \%$ soil organic matter (Rasmussen et al., 1995) at the Organic Research Station Rugballegaard, Danish Institute of Agricultural Sciences.

\subsection{Grazing systems}

Trial 1 included four grazing systems for first season heifers and sows (including pregnant gilts):

SN: sows grazing alone.

$\mathrm{HN}$ : heifers grazing alone.

MI: mixed grazing with sows and heifers simultaneously on the same paddock.

AL: alternate grazing with sows and heifers on the same paddock. The paddock was divided into two equal sub-units, which were being grazed alternately by sows and heifers at weekly intervals.

Trial 1 was conducted during the grazing season in 1998 on the same paddocks as used for the pilot Trial in 1997. The sward was composed of perennial ryegrass (Lolium perenne) and white clover (Trifolium repens), and was established with spring barley as a cover crop in 1996. There were two replicate paddocks for system $\mathrm{SN}$, and these were grazed alternately by the same group of animals (Table 1). There were no replicates of the other systems in the pilot Trial and Trial 1.

Paddocks for Trial 2 were established at a new and not previously grazed grass/clover field in 1999. The sward was established in 1998 and was composed of perennial ryegrass, white clover, red clover 
Table 1

Grazing systems and animals

\begin{tabular}{|c|c|c|c|c|c|c|c|}
\hline & \multicolumn{4}{|l|}{ Trial 1} & \multicolumn{3}{|l|}{ Trial 2} \\
\hline & \multicolumn{2}{|c|}{ Mono grazing } & \multirow{2}{*}{$\frac{\text { Mixed grazing }}{\text { Heifers }+ \text { sows }}$} & \multirow{2}{*}{$\frac{\text { Alternate grazing }}{\text { Heifers }+ \text { sows }}$} & \multicolumn{2}{|c|}{ Mono grazing } & \multirow{2}{*}{$\frac{\text { Mixed grazing }}{\text { Heifers }+ \text { sows }}$} \\
\hline & Heifers & Sows & & & Heifers & Sows & \\
\hline Season length (days) & 152 & 155 & $152 / 155$ & $152 / 155$ & 147 & 149 & 149 \\
\hline Number of paddocks ${ }^{a}$ & 1 & 2 & 1 & 1 & 2 & 2 & 2 \\
\hline Number of groups ${ }^{\mathrm{a}}$ & 1 & 1 & 1 & 2 & 2 & 2 & 2 \\
\hline Mean number of animals per group ${ }^{a}$ & 8 & 9.2 & $8+9.9$ & $8+10.1$ & 7.2 & 9.9 & $8+10.9$ \\
\hline Mean area per paddock (ha) & 1.18 & 0.55 & 1.44 & 1.44 & 0.68 & 0.51 & 1.42 \\
\hline \multicolumn{8}{|l|}{ Stocking rate $\mathrm{b}^{\mathrm{b}}$} \\
\hline Mean (number ha ${ }^{-1}$ ) & 6.8 & 16.6 & $5.5+6.9$ & $5.5+7.0$ & 10.5 & 19.2 & $5.7+7.7$ \\
\hline May (tonnes $\mathrm{ha}^{-1}$ ) & 3.1 & 8.9 & $2.6+2.6$ & $2.6+3.2$ & 2.5 & 10.9 & $1.7+3.1$ \\
\hline July (tonnes $\mathrm{ha}^{-1}$ ) & 1.4 & 2.9 & $1.2+1.3$ & $1.2+1.0$ & 2.8 & 4.7 & $1.4+2.0$ \\
\hline September (tonnes $\mathrm{ha}^{-1}$ ) & 1.6 & 3.3 & $1.4+1.3$ & $1.5+1.7$ & 1.6 & 3.2 & $1.0+1.0$ \\
\hline
\end{tabular}

${ }^{\mathrm{a}}$ In Trial 1 there was one group of animals and one paddock for each grazing system (except for sows grazing alone), whereas in Trial 2 there were two paddocks and two animal groups for each grazing system.

${ }^{\mathrm{b}}$ Calculated from the weighted averages of animal numbers or weight and grazing area during the grazing season.

(Trifolium pratense) and timothy (Phleum pratense). The alternate grazing system was not included in Trial 2, which only included the three grazing systems: SN, HN and MI. There were two replicate paddocks and two animal groups of each grazing system in Trial 2.

All systems were managed by continuous grazing, composed of a core area, where the animals grazed the whole season, and a buffer area, which was cut as appropriate and gradually included in the grazing area. The allocated area was adjusted according to weekly measurements of compressed sward heights measured by a rising plate meter. However, in heifer paddocks, sward heights in rejected grass around dung pats were not measured. The target height was $5 \mathrm{~cm}$. In Trial 1 the buffer area in the AL paddock followed the MI paddock area independently of sward height in the AL paddocks. The SN and HN paddocks were managed independently according to the sward height in the paddocks. In Trial 2 the grazing areas of all six paddocks were managed independently with the aim of achieving the same sward height for all groups of animals. The grazing area was adjusted from four to 12 times during the grazing season. Stocking rates at turn-out in May, at mid-season and late-season are given in Table 1.

The swards were not fertilised or irrigated during the growing season. The paddocks were topped if the grass was too stemmy. In Trial 1 the SN paddocks were topped on 7 July and the AL paddocks on 31
July. In Trial 2 all paddocks were topped at 23 August and the SN paddocks were further topped on 28 June.

\subsection{Animals and supplementary feeding}

The trials were conducted by using all the pregnant animals (stage up to 14 weeks post mating) from an outdoor multiplier herd of 60-70 sows, which were crossbreds of Danish Landrace, Danish Yorkshire and Danish Duroc. Initially all animals were included in the pilot Trial as mated gilts. The animals were supplied with a nose-ring. Each sow in the herd was permanently allocated to a grazing system, meaning that in the same year a sow after weaning and mating always returned to the same grazing system during her pregnancy periods. All sows were managed equally between pregnancy periods. The groups were dynamic, meaning that sows entered the systems after breeding, and sows left the systems approximately 2 weeks before expected parturition. In both Trial 1 and 2 there were on the average nine sows in each group at a time, plus one permanent resident boar. In Trial 1 the average parity number was 3.2 , there was a total of 17 , 16 and 16 sows in the SN, MI and AL systems, respectively, and the corresponding numbers of days in the systems per sow were 71, 91 and 93. In Trial 2 the average parity number was 4.9 , there was a total of 30 and 33 sows in the SN and MI systems, respectively, and the corresponding numbers of days in the systems per sow were 77 and 81 . The pigs were 
housed in three huts with straw bedding per paddock. There were separate stalls for each sow for supplementary feeding of concentrates.

The composition of the concentrate feeds for sows was, in percent of wet weight in Trial 1/Trial 2: barley $68.5 / 10.0$; wheat $10.0 / 48.5$; oats $0 / 20.0$; soya bean meal, toasted 19.0/19.0; dicalciumphosphate 1.0/1.0; $\mathrm{CaCO}_{3}$ 1.0/1.0; $\mathrm{NaCl} 0.3 / 0.3$; vitamin and trace mineral mixture $0.2 / 0.2$. The corresponding dietary contents of protein and energy were: crude protein $16.2 \%$ / 17.0\%; metabolisable energy, $\mathrm{MJ} \mathrm{kg}^{-1}$ 13.24/13.04; net energy, $\mathrm{MJ} \mathrm{kg}^{-1} 8.26 / 8.11$; feed units for pigs $\left(\mathrm{FU}_{\mathrm{p}}\right)$ per $\mathrm{kg}$ 1.07/1.05, one $\mathrm{FU}_{\mathrm{p}}$ equalling $7.72 \mathrm{MJ}$ net energy (Just, 1982). The daily amount of supplementary feed was adjusted according to the stage of pregnancy and herbage allowance in the SN system. Daily rations were, at the same stage of pregnancy, always the same in all grazing systems. In Trial 1 and 2 the average daily allocation of supplementary feed was 1.3 and $1.1 \mathrm{~kg}$, respectively, during the first 84 days of pregnancy, and 2.3 and $2.1 \mathrm{~kg}$, respectively, from day 85 to 112 of pregnancy. During the season, the overall daily amounts of concentrates averaged $1.42 \mathrm{~kg}$ in Trial 1 and $1.28 \mathrm{~kg}$ in Trial 2.

In each trial the heifers were first year grazers of the Danish Holstein breed. Before allocation to the groups, the heifers were blocked according to weight (see Table 5) and sire. Each group consisted of eight heifers, and the heifers were permanently present in their respective grazing system throughout the grazing season. However, in Trial 2 two heifers were taken out of one of the HN groups in June due to bad temper, and were not replaced. The heifers were not given any supplementary feed.

All animals were weighed when they entered and left the grazing systems, and every second week throughout the season. Individual daily weight gains for heifers were estimated as the regression coefficients from all weightings. Individual daily weight gains for sows were calculated from start and end weights. In case sows had two grazing periods, interrupted by a farrowing-lactation period, the results were pooled, whereby each sow counted as one observation. Total animal weight gains for heifers and sows per hectare were calculated from the daily body weight gains (BWG) (ls-means), the actual number of grazing days and the mean grazing area per paddock. The mean grazing area per pad- dock was calculated as the sum of allocated grazing area times grazing days, divided by the sum of grazing days.

Daily grass intake in energy units was estimated from the measured body weights and BWGs, based on energy requirements for maintenance, growth and outdoor grazing activity (Just et al., 1983; Foldager et al., 1988; Strudsholm et al., 1999; Theil, 2002; Danielsen, in preparation). Due to grazing activity and outdoor climate, the daily requirement for maintenance of sows was raised by $0.2 \mathrm{FU}_{\mathrm{p}}(1.5 \mathrm{MJ} \mathrm{NE})$ corresponding to approximately $10 \%$ extra. The daily requirement for maintenance in heifers was adjusted by approximately $5 \%$ due to outdoor grazing activity.

All animals had free access to water.

\subsection{Herbage measurements}

Sampling of herbage and simultaneous measurement of grazing height and sward height structure were carried out three times during the season in Trial 1 (week 24, 31, 39) and five times during the season in Trial 2 (week 18, 23, 28, 34, 40). Each time all measurements were taken systematically in the same $w$-route in the core and the buffer area, respectively. In the buffer area, measurements were only carried out in the part, which was included in the grazing area.

Sward height was measured as compressed sward height by a rising plate meter (size: $0.3 \times 0.3 \mathrm{~m}$, pressure: $3.8 \mathrm{~kg} \mathrm{~m}^{-2}$ ). For evaluation of sward height structure, 100 heights were measured systematically each time in all $w$-routes. In the heifer paddocks, sward height was also measured in the rejected herbage around the dung pats. If the foot of the rising plate meter was placed outside a dung patch area and the plate was reposed over the rejected grass in the dung patch, the plate meter was removed away from the dung patch to avoid over-estimation of the rejected grass. If the foot of the plate meter was placed inside an area with rejected herbage, the height was measured. To evaluate adjustment of the grazing areas additional 20 weekly measurements of the compressed sward height were carried out per paddock of the grazed herbage in between any dung patches.

Grazing height was measured by a ruler in recently grazed spots. The actual height and not the maximum height were measured. In Trial 1 there were 30 
random measurements in the core area. In Trial 2 grazing height was measured in 50 random recently bitten spots in the core area and the buffer area, respectively, and the height of the four nearest grazed leaves was measured.

The herbage mass above the actual measured grazing height was measured in eight random 0.5 $\mathrm{m}^{2}$ plots with four samples in the core area and four samples in the buffer area. The herbage was cut by electric scissors with shoes to keep the right height. The herbage was collected by hand and by a leaf suction apparatus. In the heifer-paddocks, further samples were taken around four randomly chosen dung pats and the area of rejected herbage was measured for calculating the herbage mass per area unit. The border of the dung patches was defined by the rejected grass height being the double that of the grazing height.

The herbage samples were analysed for dry matter and ash according to AOAC (1990), acid insoluble ash according to EØF (1971), crude protein by the Dumas method (Hansen, 1989), crude fibre by the method of Tecator (1978), in vitro digestibility of organic matter for cattle (IVOMD) by the method of Tilley and Terry (1963), and in vitro digestibility of organic matter for pigs (EDOM) by the method of Boisen and Fernandez (1992). The botanical composition was determined in sub-samples by hand separation. The herbage was split into grass leaves, grass stem including inflorescence and leaf sheath, white clover leaves, white clover flowers including flower stem, dead plant material and dicotyledonous weeds. In Trial 2 the samples were further split in red clover leaves and red clover stem including flowers and leaf sheath.

\subsection{Statistics}

Data were analysed using General Linear Models Procedure (Proc GLM) in PC-SAS version 8 (SAS Institute Inc., 1999). Model (1) was used to analyse the effect of grazing system on daily weight gain for sows and heifers, and results are presented as least square mean estimates. Due to variation in the number of days on treatment, this parameter was included in the model as a covariate.

$Y_{i k}=\mu+\alpha\left(W_{k}\right)+\beta\left(D_{k}\right)+\delta_{i}+\varepsilon_{i k}$ where $Y_{i k}$, individual weight gain; $\mu$, overall average; $\alpha\left(W_{k}\right)$, effect of turn-out weight $(W)$ for animal $k$; $\beta\left(D_{k}\right)$, effect of number of days in the grazing system (D) for animal $k ; \delta_{i}$, effect of grazing system $i ; i$, (alone, mixed, alternate); $\varepsilon_{i k}$, residual error, $N\left(0, \sigma^{2}\right)$ and independent.

Model (2) was used to analyse the effect of grazing system on the sward parameters, and least square mean estimates were calculated.

$Y_{i j k}=\mu+\alpha_{i}+\beta_{j}+\varepsilon_{i j k}$

where $Y_{i j k}$, the individual measurement; $\mu$, overall average; $\alpha_{i}$, effect of grazing system $i ; i,(\mathrm{HN}, \mathrm{SN}$, MI); $\beta_{j}$, effect of replicate $j ; j,(1,2) ; \varepsilon_{i j k}$, residual error, $N\left(0, \sigma^{2}\right)$ and independent.

\section{Results}

Basal facts about the grazing systems are presented in Table 1. The season length was approximately 150 days in both trials. The mean stocking rate of animals in tonnes $\mathrm{ha}^{-1}$ was higher in Trial 2 than in Trial 1, especially in mid-season (July).

Management of the grazing areas is documented in Fig. 1 as expressed by the weekly measurements of compressed sward heights. Fig. 1 shows that the sward heights were quite similar between grazing systems. However, there were two exceptions in Trial 1 , where the $\mathrm{SN}$ paddocks were generally $3 \mathrm{~cm}$ higher than the other paddocks and the AL 1-paddock, which was higher in the beginning of the season. The sward heights of the other paddocks in Trial 1 were close to the target of $5 \mathrm{~cm}$ on the average, but were generally decreasing during the seasons. The management of sward height and grazing area improved from Trial 1 to 2 , where the obtained sward heights were close to the target of 5 $\mathrm{cm}$ and quite stable throughout the season, except for a decrease during the first month. In Trial 2 the measurements were divided in core and buffer areas and Fig. 1 shows that the sward height was almost identical in the two areas.

Animal behaviour and vegetation cover were not systematically surveyed or measured, but were evaluated subjectively during the routine inspections throughout the grazing seasons. No adverse behaviour 

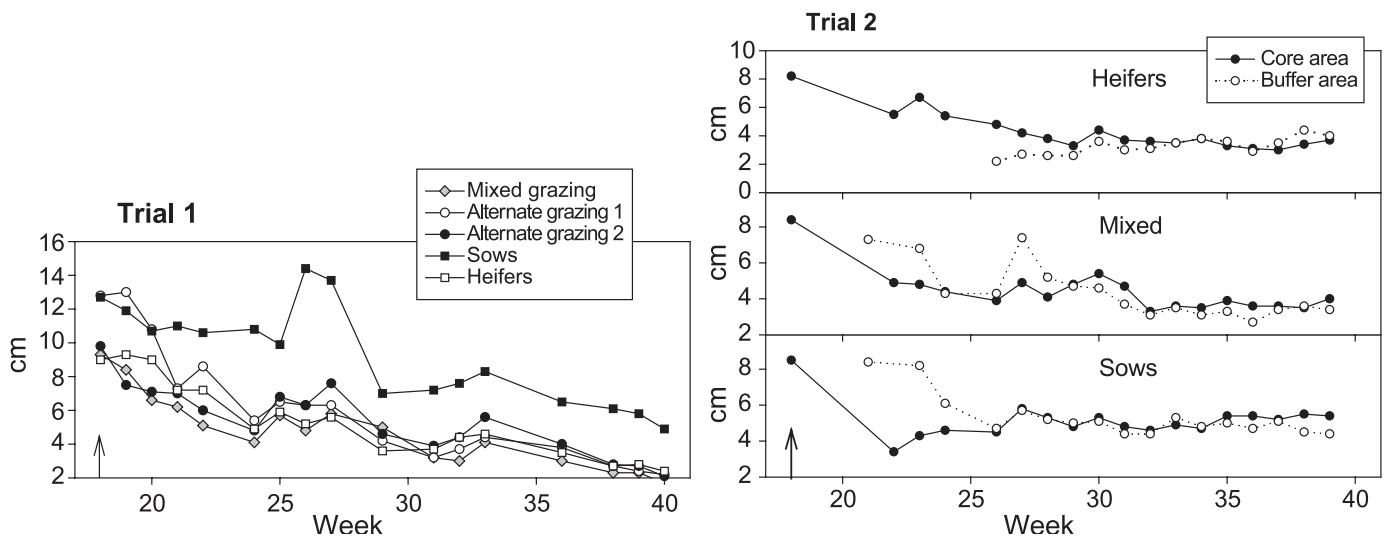

Fig. 1. Compressed sward height of the grazed herbage in between any dung patches. Recordings from the weekly measurements taken to evaluate adjustment of the grazing areas. The arrows denote the time of turn-out. In Trial 1 the sward height was a mean of the total grazing area, and in Trial 2 the measurements were grouped for core and buffer areas, respectively.

was observed between the two animal species. Sows and heifers grazed together and generally both species used the whole area of the paddocks. No systematic destruction of the vegetation cover by the sows was observed, but occasional holes occurred with higher density in the SN paddocks than in other paddocks.

The sows had no clinical parasite infections in Trial 1 or 2 . The HN heifers in Trial 2 showed indications of clinical ostertagiosis in mid-August, and all heifers in both the $\mathrm{HN}$ and MI systems were, therefore, drenched with albendazole (Roepstorff et al., in preparation). One of the HN groups in Trial 2 showed clinical signs of panaritium, and was housed for 5 days in late May and treated with antibiotics.

The mean temperature and radiation at $2 \mathrm{~m}$ height for the period from May 1 to October 15 were nearly the same in the two experiments; $13.1{ }^{\circ} \mathrm{C}$ and $14.0 \mathrm{MJ}$ $\mathrm{m}^{-2}$ per day in 1998 and $13.8{ }^{\circ} \mathrm{C}$ and $14.4 \mathrm{MJ} \mathrm{m}^{-2}$ per day in 1999. Also the temperatures during the season were nearly the same. The precipitation, however, varied between the years. The total precipitation in the grazing season was $547 \mathrm{~mm}$ in Trial 1 (1998) and $430 \mathrm{~mm}$ in Trial 2 (1999). Even though the total precipitation was relatively high in 1998 , there was a very dry period in spring and early summer. In May and June the precipitation was only $76 \mathrm{~mm}$ in 1998 compared with $154 \mathrm{~mm}$ in 1999. In 1998 the sward was visibly drought stressed in that period. A high rainfall in the beginning of July, $208 \mathrm{~mm}$ over 1 week, changed the situation and the precipitation in the summer months July and August was $324 \mathrm{~mm}$ in
1998 compared to $124 \mathrm{~mm}$ in 1999. In 1999 the relatively low rainfall in July and August caused the sward to show symptoms of drought stress.

\subsection{Sward height structure}

Sward height structure is shown in Fig. 2 for the core areas. The figure shows the proportion of the measurements, which was higher than or similar to a given height. The swards in the sow and mixed grazed paddocks were evenly grazed, whereas the heifer and alternately grazed paddocks varied more. The figure shows the mean for the whole grazing season, but in general the course of the curves was consistent during the whole season (data not shown). In Trial 1 the two sub-units in the alternately grazed paddocks became very different shortly after turn-out, as there was a lot of rejected herbage in one of them in which the sows started grazing at turn-out (paddock AL 1 in Fig. 1). This was probably caused by the lower intake by the sows than the heifers compared with the herbage growth rate. In the core area this rejection continued throughout the whole grazing season, which is reflected in Fig. 2, whereas it is not reflected in the mean for the whole paddock in Fig. 1. Ten centimetres were taken as the average limit for residual grass when interpretation of the results in Fig. 2 was made. On average, the proportion of area with sward height above $10 \mathrm{~cm}$ were $21 \%$ and $42 \%$ in the two sub-units of the alternately grazed paddocks, and $18 \%$ and $7 \%$ in heifer and mixed grazed paddocks, respectively. 

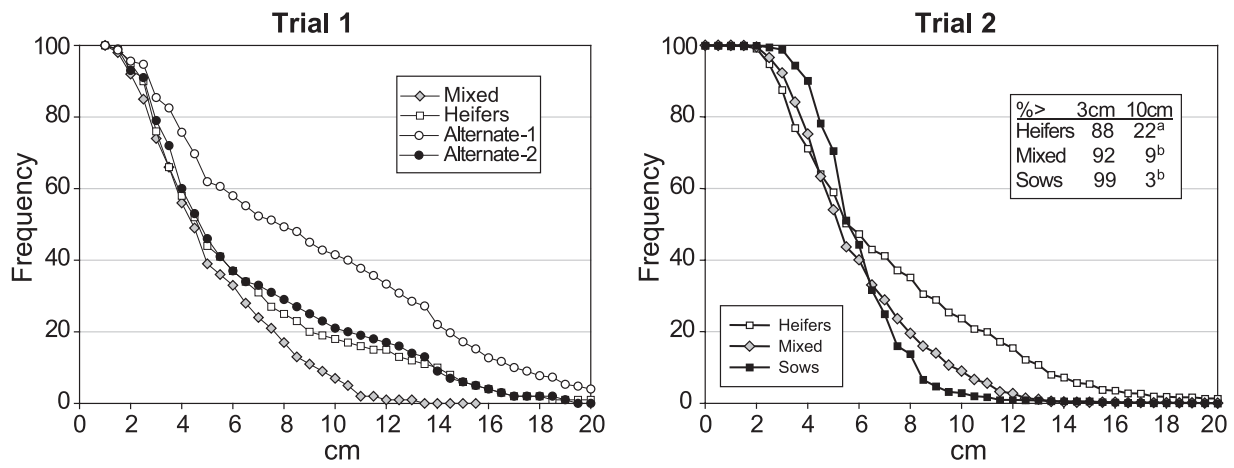

Fig. 2. Compressed sward height structure, expressed as a proportion of measurements above or similar to a certain height, in the core area in Trial 1 and 2 based on a mean of the measurements during the grazing season.

In Trial 2 the sow paddocks were the most evenly grazed with no rejected areas around the sow dung pats. The few areas, where the sward height was above $7-8 \mathrm{~cm}$, were due to other causes of rejection. Nearly all measurements were above $3 \mathrm{~cm}$ (Fig. 2). The heifer paddocks had the typical structure for cattle grazing with high rejected herbage around the dung pats, and on average $22 \%$ of the area in the heifer paddocks had a sward height above $10 \mathrm{~cm}$. On the other hand the heifers sometimes grazed to a lower height than the sows, as $12 \%$ of the area was below 3 $\mathrm{cm}$, and thus the grazed areas varied more in height than in the sow paddocks. The sward height structure in the paddocks with mixed grazing was in between the structure in heifer and sow paddocks, but appeared mostly as the sow paddock. There was limited amount of rejected grass/clover around the heifer dung pats in the mixed paddocks, and on average, there was only $9 \%$ of the area with sward height above $10 \mathrm{~cm}$.

The buffer area generally showed the same sward structure as the core area. This is shown in Fig. 3 for the last two registration dates in Trial 2. The animals did not graze the buffer area to a lower height than the core area. There was only one characteristic difference: the area with rejected grass was larger in the core area than in the buffer area. On average, $10 \%$ of the core area was above $10 \mathrm{~cm}$ compared to only $6 \%$ in the buffer area.

\subsection{Grazing height}

The mean grazing height was lowest in the heifer paddocks both in the core and in the buffer area in Trial 2 (Table 2). The grazing method of the heifers and the sows caused not only a different structure of the sward at macro level, as shown in Figs. 2 and 3, but also at the micro level (bite structure), as shown by the standard deviation in Table 2. The variation in the height of grazed leaves or stems was highest in sow paddocks and lowest in heifer paddocks. Thus, the bites of the heifers were more even than that of the sows.

\subsection{Botanical composition}

The grazing system had considerable effect on the botanical composition of the sward above grazing height. Table 3 shows results for the core area, but the effects were in general the same in the buffer area

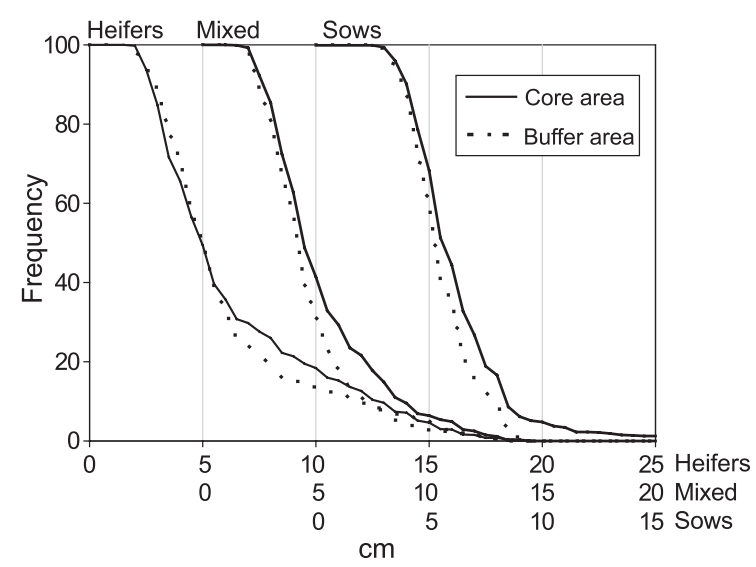

Fig. 3. Compressed sward height structure in the core and buffer area in Trial 2. Mean of the last two recordings on 26 August and 1 October. Individual $x$-axes are shown for the different grazing systems. 
Table 2

Grazing height $(\mathrm{cm})$ measured in 50 points five times during the grazing season in Trial 2

\begin{tabular}{lllll}
\hline Area & System & Mean $^{1}$ & Mean of S.D. $^{2}$ & Minimum $^{3}$ \\
\hline Core & Heifers & $4.9^{\mathrm{b}}$ & $1.2^{\mathrm{b}}$ & $3.9^{\mathrm{c}}$ \\
& Mixed grazing & $6.8^{\mathrm{a}}$ & $1.8^{\mathrm{a}}$ & $5.0^{\mathrm{a}}$ \\
& Sows & $6.3^{\mathrm{a}}$ & $1.9^{\mathrm{a}}$ & $4.4^{\mathrm{b}}$ \\
\multirow{2}{*}{ Buffer } & Heifers & $4.6^{\mathrm{b}}$ & $1.3^{\mathrm{b}}$ & 3.3 \\
& Mixed grazing & $5.6^{\mathrm{ab}}$ & $1.7^{\mathrm{ab}}$ & 3.9 \\
& Sows & $6.4^{\mathrm{a}}$ & $2.1^{\mathrm{a}}$ & 4.3 \\
\hline
\end{tabular}

The four nearest grazed leaves or stems were measured at each point. Means with the same letter in superscript within core or buffer are similar $(P>0.05)$.

${ }^{1}$ Mean of the mean heights per point.

${ }^{2}$ Mean of the standard deviations per point.

${ }^{3}$ Mean of the lowest measurements per point.

(data not shown). In both trials there was a lower content of clover in the sow paddocks, and the effect appeared very soon after turn-out (Fig. 4). In Trial 2 there was a relatively low white clover content at turnout $(16.4 \%$ of DM on average), and this content increased with heifer grazing and with mixed grazing, and peaked in July, whereas it decreased with sow grazing (Fig. 4). The content of red clover was relatively high at turn-out (39.7\% of DM on average), and decreased during the grazing season for all systems (Fig. 4). But the decrease seemed to be highest with sow grazing. Dicotyledonous weed (not shown) constituted only a small proportion in all paddocks, $0-3 \%$ of dry matter. The amount of dead plant material was relatively high in Trial 1 , which seemed to be caused by drought stress especially in the first third of the grazing season. In Trial 2 the amount of dead plant material was highest in the sow paddocks and lowest in the heifer paddocks, which was also in agreement with the appearance (Table 3).

In both trials the grass on the sow paddocks was more stemmy than on the heifer and mixed grazed paddocks. In Trial 2 the stem content of grass dry matter on the sow paddocks was double the stem content at heifers grazing and more stemmy than in the rejected grass around dung pats in the heifer paddocks (Table 3), even though the sow paddocks were topped twice and the others only once. The stems were evenly distributed in the sow paddocks and the sows grazed in between the stems, which seems to be possible because of the small snout and the relatively narrow bite of the sows, and therefore, the appearance of the sward was quite different to the heifer paddocks. In Trial 1 there was a very high stem content at the alternate grazed paddock in the core area (Table 3), which was due to high herbage mass and rejection in one of the sub-units.

As mentioned above the sows seemed to select for clover when grazing, because the content of both white and red clover decreased significantly after turn-out. Looking at the clover species only, the sows seemed to prefer clover flowers more than clover leaves, as there was a tendency of a lower content of both white clover flowers and red clover flowers in per cent of white and

Table 3

Botanical composition above grazing height

\begin{tabular}{|c|c|c|c|c|c|c|c|c|c|c|}
\hline & \multicolumn{5}{|c|}{ Trial 1} & \multicolumn{5}{|c|}{ Trial 2} \\
\hline & \multicolumn{3}{|c|}{ Mono grazing } & \multirow{3}{*}{$\begin{array}{l}\text { Mixed } \\
\text { grazing }\end{array}$} & \multirow{3}{*}{$\begin{array}{l}\text { Alternate } \\
\text { grazing }\end{array}$} & \multicolumn{3}{|c|}{ Mono grazing } & \multirow{3}{*}{$\begin{array}{l}\text { Mixed } \\
\text { grazing }\end{array}$} & \multirow[t]{3}{*}{$P$-value } \\
\hline & \multicolumn{2}{|c|}{ Heifers } & \multirow[t]{2}{*}{ Sows } & & & \multicolumn{2}{|c|}{ Heifers } & \multirow[t]{2}{*}{ Sows } & & \\
\hline & Bite & Rejected & & & & Bite & Rejected* & & & \\
\hline \multicolumn{11}{|l|}{ Proportion of total DM: } \\
\hline Grass & 51.6 & 55.9 & 65.9 & 66.0 & 64.9 & $37.6^{\mathrm{b}}$ & 42.6 & $67.8^{\mathrm{a}}$ & $51.2^{\mathrm{ab}}$ & 0.05 \\
\hline White clover & 22.1 & 20.3 & 13.0 & 19.7 & 19.6 & $30.7^{\mathrm{a}}$ & 19.4 & $8.3^{\mathrm{c}}$ & $18.8^{\mathrm{b}}$ & 0.0006 \\
\hline Red clover & & & & & & 20.6 & 21.8 & 6.1 & 14.7 & 0.15 \\
\hline Dead material & 26.1 & 23.2 & 21.1 & 14.2 & 15.6 & $9.0^{\mathrm{b}}$ & 15.8 & $15.8^{\mathrm{a}}$ & $12.2^{\mathrm{ab}}$ & 0.04 \\
\hline \multicolumn{11}{|c|}{ Proportion of the single species-DM: } \\
\hline Grass stem and flowers & 30.0 & 38.8 & 41.4 & 35.2 & 48.8 & 15.6 & 27.3 & 33.2 & 22.6 & 0.11 \\
\hline White clover flowers & 18.1 & 21.6 & 4.2 & 5.0 & 10.7 & 3.8 & 16.0 & 1.7 & 4.7 & 0.49 \\
\hline Red clover stem and flowers & - & - & - & - & - & 19.1 & 37.6 & 8.0 & 14.9 & 0.43 \\
\hline
\end{tabular}

The proportion (\%) of the single species and dead plant material of total dry matter and the proportion (\%) of stem and flowers of the dry matter of the species concerned. Mean over season in the core area. Means with the same superscript within trial and row are similar $(P>0.05)$.

* Rejected herbage (dung patch) is not included in the statistical analyses. 


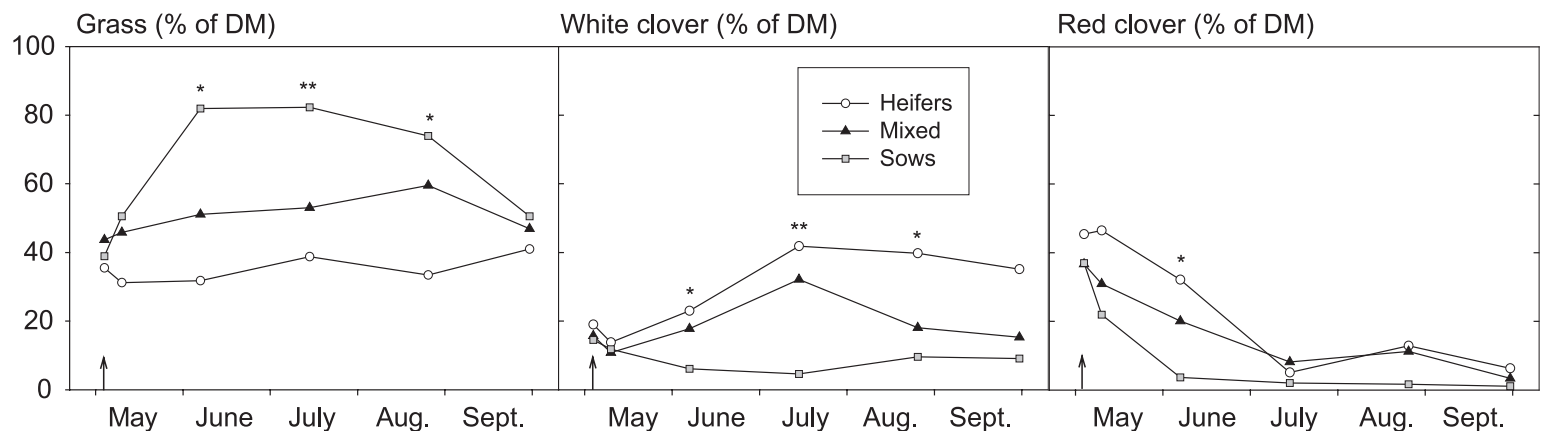

Fig. 4. Botanical composition of the herbage above grazing height in the core area throughout the grazing season of Trial 2 . No measurements were taken in the rejected grass around dung patches in the heifer paddocks. The arrow denotes the time of turn-out. $* P<0.05, * * P<0.01$.

red clover dry matter, respectively, in the sow paddocks compared with the other systems (Table 3).

\subsection{Herbage quality}

The herbage quality of the core areas is shown in Table 4 and Fig. 5. The quality and the differences between grazing systems were generally lower in Trial 1 than in Trial 2. In Trial 1 the protein content and digestibility of organic matter were highest in the mixed grazing paddocks, the heifer paddocks having the lowest quality, although the differences were relatively small. This could be due to periods with drought stress in 1998, as the heifer paddock especially seemed to be drought stressed. In Trial 2 the forage crude protein content and EDOM for pigs were highest in the heifer paddocks and lowest in the sow paddocks, the mixed grazed paddocks being in between. In contrast, the IVOMD for cattle was not affected by grazing system. The effects of the grazing systems were in general the same in the buffer area as in the core area (data not shown). The herbage in the sow paddocks was visibly dirtier, and the content of acid insoluble ash was also higher (Table 4). In Trial 2 the content of crude protein was lowest in the sow paddocks with the lowest content of clover, and the protein content followed the content of clover throughout the grazing season (Figs. 4 and 5). The content of crude fibre showed the opposite pattern (data not shown). The forage EDOM for pigs decreased considerably during the grazing season in Trial 2 (Fig. 5), especially in the sow paddocks. The forage IVOMD for cattle showed the same trend (data not shown).

\subsection{Animal weight gain and grass intake}

Table 5 shows daily BWG and estimated grass intake in heifers and sows by grazing system. Heifers

Table 4

Quality of herbage above grazing height in the core area of the paddocks

\begin{tabular}{|c|c|c|c|c|c|c|c|c|}
\hline & \multicolumn{4}{|l|}{ Trial 1} & \multicolumn{4}{|l|}{ Trial 2} \\
\hline & \multicolumn{2}{|c|}{ Mono grazing } & \multirow{2}{*}{$\begin{array}{l}\text { Mixed } \\
\text { grazing }\end{array}$} & \multirow{2}{*}{$\begin{array}{l}\text { Alternate } \\
\text { grazing }\end{array}$} & \multicolumn{2}{|c|}{ Mono grazing } & \multirow{2}{*}{$\begin{array}{l}\text { Mixed } \\
\text { grazing }\end{array}$} & \multirow[t]{2}{*}{$P$-value } \\
\hline & Heifers $^{1}$ & Sows & & & Heifers $^{1}$ & Sows & & \\
\hline Crude protein $(\%$ of $\mathrm{DM})$ & 16.8 & 18.6 & 21.0 & 20.1 & $25.8^{\mathrm{a}}$ & $18.4^{\mathrm{c}}$ & $23.9^{\mathrm{b}}$ & 0.002 \\
\hline Crude fibre $(\%$ of $\mathrm{DM})$ & 19.6 & 22.3 & 21.4 & 21.4 & 15.6 & 17.0 & 16.9 & 0.390 \\
\hline Digest., cattle $(\%$ of OM) & - & - & - & - & 76.5 & 74.7 & 76.3 & 0.070 \\
\hline Digest., pigs ${ }^{3}(\%$ of $\mathrm{OM})$ & 48.8 & 51.8 & 54.3 & 53.3 & $68.7^{\mathrm{a}}$ & $55.8^{\mathrm{c}}$ & $63.6^{\mathrm{b}}$ & 0.007 \\
\hline Acid insoluble ash (\% of DM) & - & - & - & - & $3.9^{\mathrm{b}}$ & $8.8^{\mathrm{a}}$ & $4.5^{\mathrm{b}}$ & 0.050 \\
\hline
\end{tabular}

Calculated as the mean of three (Trial 1) and five (Trial 2) measurements during the season, and expressed as percent of dry matter (DM) and organic matter $(\mathrm{OM})$, respectively. Means with the same letters superscript within trial and row are similar $(P>0.05)$.

${ }^{1}$ Analyses of bite grass. Rejected grass (dung patches) is not included.

${ }^{2}$ In vitro digestibility of organic matter for cattle (IVOMD) by the methods of Tilley and Terry (1963); Weisbjerg and Hvelplund (1992).

${ }^{3}$ In vitro digestibility of organic matter for pigs (EDOM) by the method of Boisen and Fernandez (1992). 

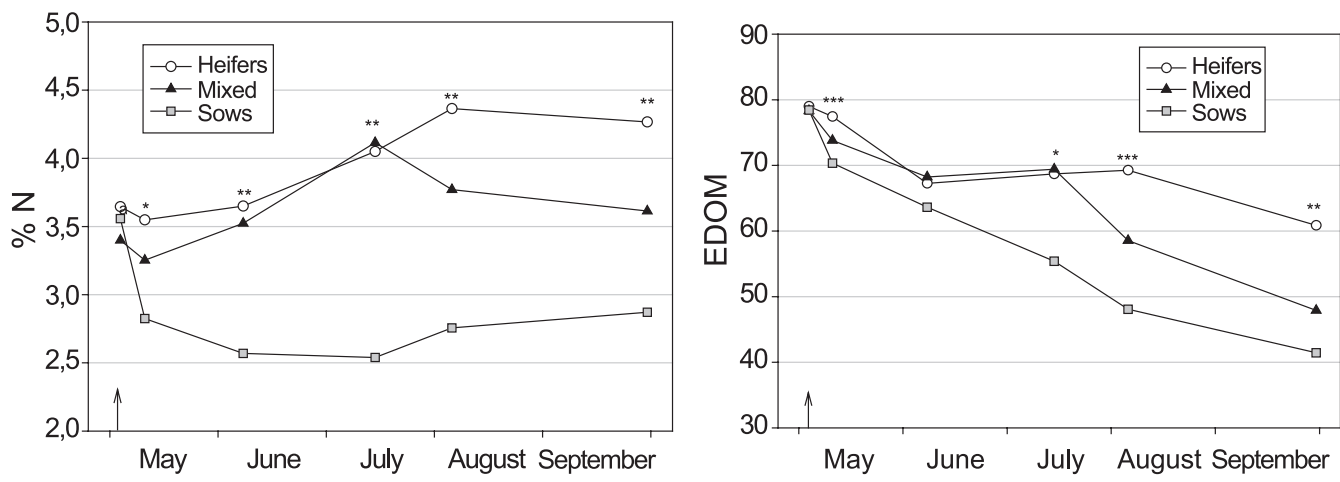

Fig. 5. Herbage quality expressed as nitrogen content $(\% \mathrm{~N})$ and in vitro organic matter digestibility for pigs (EDOM) during the grazing season of Trial 2. No measurements were taken in the dung patches in the heifer paddocks. The arrow denotes the time of turn-out. $* P<0.05$, ** $P<0.01, * * * P<0.001$.

grazing mixed or alternately with sows gained significantly more weight (between +140 and +250 g per day) than heifers grazing alone in both experiments. The lower average weight gain in heifers grazing alone was primarily due to a depressed growth rate from July to August. In both experiments heifer growth rates were at the same level for all groups until July, where the growth rates decreased for heifers grazing alone. From mid-August the depression of growth rates in heifers grazing alone ceased, and the growth rates again approached the rates for heifers grazing mixed or alternately with sows (curves are

Table 5

BWG and estimated grass intake in heifers and sows by grazing group

\begin{tabular}{|c|c|c|c|c|c|c|c|}
\hline & \multicolumn{4}{|l|}{ Trial 1} & \multicolumn{3}{|l|}{ Trial 2} \\
\hline & Mono & Mixed & Alternate & $P$-value & Mono & Mixed & $P$-value \\
\hline \multicolumn{8}{|l|}{ Heifers } \\
\hline Turn-out weight (kg) & $199 \pm 21$ & $204 \pm 21$ & $209 \pm 21$ & ns & $169 \pm 10$ & $166 \pm 9$ & ns \\
\hline Daily BWG $(\mathrm{g})^{1}$ & $863 \pm 40^{\mathrm{a}}$ & $1004 \pm 40^{\mathrm{b}}$ & $1080 \pm 40^{\mathrm{b}}$ & 0.004 & $869 \pm 48^{\mathrm{a}}$ & $1121 \pm 45^{\mathrm{b}}$ & 0.0006 \\
\hline \multicolumn{8}{|l|}{ Grass intake $^{2}$} \\
\hline NE per day (MJ) & 40.0 & 48.9 & 48.9 & & 42.2 & 56.1 & \\
\hline $\mathrm{FU}_{\mathrm{c}}$ per day & 5.1 & 6.2 & 6.2 & & 5.4 & 7.1 & \\
\hline \multicolumn{8}{|l|}{ Sows } \\
\hline Sow parity number & 3.1 & 3.1 & 3.4 & ns & 4.9 & 4.8 & ns \\
\hline Turn-out weight (kg) & 201 & 202 & 219 & ns & 242 & 238 & ns \\
\hline Grazing days per sow & 71 & 91 & 93 & & 77 & 81 & ns \\
\hline Daily BWG $(\mathrm{g})^{3}$ & $515 \pm 49$ & $564 \pm 49$ & $576 \pm 50$ & ns & $508 \pm 37$ & $550 \pm 35$ & ns \\
\hline \multicolumn{8}{|l|}{ Concentrate supplement } \\
\hline NE per sow per day (MJ) & 11.7 & 11.7 & 11.7 & & 10.3 & 10.3 & \\
\hline $\mathrm{FU}_{\mathrm{p}}$ per sow per day & 1.5 & 1.5 & 1.5 & & 1.3 & 1.3 & \\
\hline \multicolumn{8}{|l|}{ Grass intake ${ }^{4}$} \\
\hline NE per day (MJ) & 8.8 & 9.5 & 10.1 & & 11.7 & 12.1 & \\
\hline $\mathrm{FU}_{\mathrm{p}}$ per day & 1.15 & 1.23 & 1.31 & & 1.52 & 1.57 & \\
\hline
\end{tabular}

Means with the same letters superscript within trial and row are similar $(P>0.05)$. Abbreviations: BWG, body weight gain; DE, digestible energy; DM, dry matter; MJ, megajoule; NE, net energy; $\mathrm{FU}_{\mathrm{c}}$, feed unit for cattle (Weisbjerg and Hvelplund, 1993); $\mathrm{FU}_{\mathrm{p}}$, feed unit for pigs (Just, 1982).

${ }^{1}$ Least square means of individual daily weight gains for heifers were calculated from regression coefficients from weighings every second week.

${ }^{2}$ Estimated from ls-mean daily BWG based on Foldager et al. (1988). $1 \mathrm{FU}_{\mathrm{c}}=7.89 \mathrm{MJ}$ NE.

${ }^{3}$ Least square means of individual daily weight gains for sows were calculated from start and end weights.

${ }^{4}$ Estimated from maintenance and ls-mean daily BWG based on Just et al. (1983); Danielsen, in preparation. 1 FU $=7.72$ MJ NE. 
Table 6

Annual yield in animal weight gain and grass intake, and estimated herbage mass above grazing height

\begin{tabular}{|c|c|c|c|c|c|c|c|}
\hline & \multicolumn{4}{|l|}{ Trial 1} & \multicolumn{3}{|l|}{ Trial 2} \\
\hline & \multicolumn{2}{|c|}{ Mono grazing } & \multirow{2}{*}{$\frac{\text { Mixed grazing }}{\text { Heifers }+ \text { sows }}$} & \multirow{2}{*}{$\frac{\text { Alternate grazing }}{\text { Heifers }+ \text { sows }}$} & \multicolumn{2}{|c|}{ Mono grazing } & \multirow{2}{*}{$\frac{\text { Mixed grazing }}{\text { Heifers }+ \text { sows }}$} \\
\hline & Heifers & Sows & & & Heifers & Sows & \\
\hline Herbage mass $\left(\mathrm{kg} \mathrm{ha}^{-1}\right)$ & 420 & 495 & 378 & 548 & $569^{*}$ & 711 & 468 \\
\hline Weight gain $\left(\mathrm{kg} \mathrm{ha}^{-1}\right)$ & 893 & 1189 & $847+540$ & $911+564$ & 1354 & 1320 & $928+572$ \\
\hline Grass intake pigs $\left(\mathrm{FU}_{\mathrm{p}} \mathrm{ha}^{-1}\right)$ & & 2845 & 1378 & 1489 & & 3891 & 1650 \\
\hline Grass intake heifers $\left(\mathrm{FU}_{\mathrm{c}} \mathrm{ha}^{-1}\right)$ & 5598 & & 5683 & 6324 & 8020 & & 6081 \\
\hline
\end{tabular}

* Measured between dung patches. Mean of herbage mass in dung patches was $1041 \mathrm{~kg} \mathrm{DM} \mathrm{ha}^{-1}$.

shown in Roepstorff et al., in preparation). The same pattern of results was obtained in the pilot Trial (results not shown). As daily grass intake was estimated from daily BWGs it follows the same pattern as the weight gain between grazing systems (Table 5).

Sows grazing mixed or alternately with heifers had a slightly higher weight gain in Trial $1,+49$ and +61 g per day, respectively, relative to sows grazing alone. In Trial 2 sows grazing mixed with heifers also had a slightly higher weight gain of $+42 \mathrm{~g}$ per day relative to sows grazing alone. On the average, the sows were supplemented with $12 \%$ less energy in concentrates in Trial 2 than in Trial 1.

The total animal weight gain and the estimated grass intake per hectare are shown in Table 6. In both trials the summed animal weight gain (heifers + sows) and estimated grass intake per hectare were higher in the mixed and alternate grazing systems compared with the systems where sows and heifers grazed alone.

For all systems the estimated grass intake per animal per day (Table 5) and per hectare (Table 6) was higher in Trial 2 than in Trial 1, and the stocking rates (number and $\mathrm{kg} \mathrm{ha}^{-1}$ ) were also higher in Trial 2 than in Trial 1. A rough estimate of intake as $\mathrm{kg} \mathrm{DM}$ $\mathrm{ha}^{-1}$ in the different systems has been calculated from intake of feed units (Table 6) under the assumption that $1 \mathrm{FU}_{\mathrm{p}}$ and $1 \mathrm{FU}_{\mathrm{c}}$ equals $2 \mathrm{~kg} \mathrm{DM}$ and $1.1 \mathrm{~kg} \mathrm{DM}$, respectively. The rounded estimates of intake of $\mathrm{kg}$ $\mathrm{DM} \mathrm{ha}{ }^{-1}$ were for Trials 1 and 2, respectively, 6,200 and 8,800 in the HN system, 5,700 and 7,800 in the SN system, and 9,000 and 10,000 in the MI system.

\section{Discussion}

The two trials had a slightly different focus in that Trial 1 primarily focused on the sows whereas heifers were equally included in Trial 2. Before the start of the projects, there was no knowledge about the possibilities for heifers and sows to graze together, and the main goals for the pilot Trial and Trial 1 were to improve grazing management for sow grazing and examine different grazing systems in that respect. Because the mixed grazing system was successful in Trial 1, the subject was further examined in Trial 2, which was planned with replicates. The results from the field measurements in Trial 2 were, therefore, more statistically precise and most of the discussion of relationships between animals and the sward is based on data from Trial 2.

Mixed or alternate grazing with heifers and sows consistently improved the individual weight gain in both heifers and sows, compared with grazing each species alone. However, the positive effect was statistically significant only for heifers. The herbage quality of the MI and AL systems was better compared with the SN system, but not unambiguously better compared with the HN system. The total animal weight gain (heifers plus sows) and estimated grass intake per hectare were also higher in the mixed and alternate grazing systems compared with the systems where sows and heifers grazed alone.

The sows grazed selectively as they preferred clover rather than grass and grass leaves rather than grass stem. There were no records of sward deterioration, but a few turnovers of the sward were observed. Animal behaviour was not systematically surveyed, but no adverse behaviour was observed between the two animal species. However, the management of the alternate grazing system was more laborious than the mixed grazing system, due to the weekly shifts of animal groups and increased need for topping. Herbage quality, proportion of rejected herbage and load of gastro-intestinal nematodes in heifers 
(Roepstorff et al., in preparation) could positively have influenced animal weight gain per day and hectare in the MI and AL systems in this study.

\subsection{Sows}

The individual daily weight gain in sows (BWG) was only slightly and non-significantly higher in the MI and AL systems ( $+8 \%$ to $12 \%$ ) compared with the SN system. However, the mean daily BWG exceeded $500 \mathrm{~g}$ in all the systems, which is generally above normal targets for pregnant sows. The recorded levels of gain are in agreement with results reported by Danielsen and Vestergaard (2001). Meanwhile NRC (1998) recommended a total pregnancy gain of $45 \mathrm{~kg}$, corresponding to $400 \mathrm{~g}$ daily, as a reasonable target. Close and Cole (2000) recommended a maternal gain of $5-45 \mathrm{~kg}$ depending on parity number with the highest demands for gilts and young sows. By an addition of $20 \mathrm{~kg}$ gain for the foetus production, this recommendation corresponds to a total gain of 25-65 $\mathrm{kg}$ per pregnancy, which by an average consideration likewise amounts to approximately $400 \mathrm{~g}$ per day.

By comparison of the BWG of sows in the different systems, the supplementary concentrate feeding could partly have blurred a possible effect of the systems. In order to have a regular basis for comparisons, the plane of daily feeding of concentrates was similar for all systems, but the schedule for daily individual amounts was based on the conditions of the $\mathrm{SN}$ system. Thus, possibly sows in the AL and MI systems could have reached satisfactory BWG at a lower level of concentrate allotment.

The NE value of grass intake of sows was estimated as the difference between the sow's daily NE requirements for maintenance plus recorded gain and the NE in concentrate. By this estimation, grass intake constituted from $42 \%$ to $46 \%$ of the daily energy intake in Trial 1 , and $55 \%$ in Trial 2, which corresponds to an intake of approximately $2.0-2.5 \mathrm{~kg}$ grass/clover organic matter per sow per day. This level of grass intake corresponds well with the results of Sehested et al. (1999) and Rivera Ferre et al. (2001), both using the $n$-alkane-method to estimate grass intake in grazing sows supplemented with concentrates at a comparable level.

By the limitation of daily allowances of concentrate for grazing sows, it is important to ensure that their requirements for essential nutrients are met. In relation to Danish recommendations (The National Committee for Pig Breeding, Health and Production, 2002), none of the important nutrient groups would be insufficient by feeding as done in these experiments. By way of a combination of $1 \mathrm{~kg}$ concentrate and $2 \mathrm{~kg} \mathrm{DM}$ of grass/clover from grazing per day, this would supply sows with approximately $2 \mathrm{FU}_{\mathrm{p}}$ and simultaneously fulfil all recommended nutrient requirements. Calculations reveal that by this combination of concentrate and grass/clover, the dietary concentrations of both proteins, essential amino acids, minerals and vitamins are in excess of the recommendations. Thus, there is a potential for reducing the dietary concentrations of nutrients in the concentrates supplemented.

The sows grazed selectively in this study, and the content of both red and white clover in the SN paddocks decreased rapidly after turnout. This was confirmed by Nissen (2000), who studied selection five times during the season in Trial 2. A small part of the buffer area $\left(100-200 \mathrm{~m}^{2}\right)$ was enclosed in the grazing area and the botanical composition was measured before and after two grazing days. In the SN paddocks the grass content increased by $18 \%$ units and the red and white clover decreased by $12 \%$ and $6 \%$ units, respectively, during the 2 days. In the $\mathrm{HN}$ paddocks the corresponding changes were an increase of $4 \%$ of grass, a reduction of $4 \%$ of red clover and $0 \%$ of white clover. The MI paddocks were intermediate. Further, the stem content increased more over the 2 days in the SN paddocks than in the others (Nissen, 2000). The higher grazing selectivity performed by the sows for the part of the herbage with high digestibility and low breakage strength than the heifers, might be possible due to the narrower bite of the sows. The narrow bite and the grazing manner also affected the sward structure at the micro level, as the bite area of the sows was more uneven than that of the heifers. The grazing manner could also be the reason for the higher content of dead plant material in paddocks, where sows were grazing. It was observed that the sows lost a greater part of the herbage than the heifers during biting and chewing. Thus, the botanical composition of the herbage was more optimal for the sows in the MI paddocks than in the SN paddocks. This observation is in agreement with the improvement (not significant) of weight gain and estimated 
intake of NE from grazing by the MI sows in both trials.

In this study the sows were nose-rung to prevent them from destroying the sward by rooting. Watson and Edwards (1997) observed that sows without nosering reduced vegetation cover to $10 \%$ within a month. There were no data registrations on sward deterioration, but very few turnovers of the sward were observed. The nose-ring seems to be a precondition for the relatively high intake under grazing by the sows (Watson and Edwards, 1997). However, there was more soil on the herbage in the SN paddocks, which might indicate some rooting behaviour. Furthermore, the sows tread with a higher specific cloven pressure than the heifers, and this could have resulted in a higher soil contamination of the herbage, primarily due to stirring up mud during wet conditions.

\subsection{Heifers}

The daily BWG of heifers grazing mixed or alternately with sows was significantly higher than from heifers grazing alone in both experiments. The increments in weight gain were $16 \%$ and $25 \%$ in Trial 1 and $29 \%$ in Trial 2 . The availability and quality of the herbage will influence the potential weight gain that can be obtained in grazing cattle. However, the obtained weight gains in heifers did not seem to be related to either sward height or herbage mass above grazing height. The grazing areas were adjusted according to a compressed sward height at $5 \mathrm{~cm}$, which on the average was obtained in both the $\mathrm{HN}$ and MI systems in both trials. The herbage mass was lower in the MI system compared with the HN system in both trials, whereas the weight gain in heifers showed the opposite effect. This indicates that herbage allowance was not a limiting factor for weight gain in heifers in this study. However, the differences in sward structure between the MI and the $\mathrm{HN}$ systems might have influenced grazing behaviour of the heifers and thereby perhaps their herbage intake.

The herbage quality in Trial 2 was high and equal between the $\mathrm{HN}$ and MI paddocks with respect to digestibility and content of energy and protein. In Trial 1 the herbage crude protein content was relatively low in the HN paddock, but the actual level was not limiting for heifer growth rate (Strudsholm et al., 1999). The obtained weight gain level corresponds on the average (across systems) to the theoretically expected weight gain on an ad libitum grass/clover diet of the given quality (Andersen et al., 2002), but still there were significant differences in weight gain between heifers in the different systems. At the obtained level of herbage quality, the theoretical weight gain in heifers would be limited only by intake capacity (Strudsholm et al., 1999; Andersen et al., 2002), provided that the allowance was not limiting. The intake capacity in heifers depends primarily on body weight (Ingvartsen, 1994; Andersen, 1996; Strudsholm et al., 1999), but the turn-out weight of the heifers did not differ between the grazing systems. It is, however, possible that the quality of herbage actually grazed by the heifers differed from the measured herbage quality due to selection. On the other hand, this assumption is not supported by the results of Nissen (2000). In the HN paddocks the grass content only increased by $4 \%$ units and the red and white clover decreased by $4 \%$ and $0 \%$ units, respectively, during 2 days in a new ungrazed area (Nissen, 2000).

From the present data it is not possible to distinguish differences in herbage-intake and differences in herbage-utilisation between HN and MI heifers. However, it could be speculated that the differences in heifers weight gain between the HN and MI systems was partly caused by a different load of gastrointestinal nematodes (Roepstorff et al., in preparation).

\subsection{Grazing systems}

Alternate and mixed grazing by sows and heifers showed similar positive results with respect to BWG. However, the management of the alternate grazing system was more laborious than the mixed grazing system, due to the weekly shifts of animal groups and increased need for topping. Moreover, it was difficult to obtain a reasonable balance between herbage allowance, herbage quality and intake with the weekly shifts of heifers and sows, probably because the two groups had a very different potential for herbage intake. This problem showed up as a lot of rejected herbage in the AL subunit where the sows started grazing at turn-out. Due to the mentioned drawbacks and due to a wish to make space for replicates of the applied grazing systems, it was decided not to include the alternate grazing system in Trial 2. 
Animal behaviour was not systematically surveyed, but no adverse behaviour was observed between the two animal species. Sows and heifers grazed in between each other and generally both species used the whole area of the paddocks.

In Trial 1 the mean increments in animal weight gain per hectare were approximately $33 \%$ and $42 \%$ in the MI and AL systems, respectively, whereas it was approximately $12 \%$ in the MI system in Trial 2, compared with the mean of the systems where sows and heifers grazed alone. The corresponding mean increment in estimated herbage intake per hectare was around $76 \%$ in the MI and AL systems in Trial 1 , whereas it was approximately $30 \%$ in the MI system in Trial 2. However, herbage mass per hectare and sward height was not increased in the $\mathrm{MI}$ and $\mathrm{AL}$ systems. The differences between increment in animal weight gain and herbage intake are in part accounted for by the different relative proportion of feed supplement in Trial 1 and 2. The consistent positive effect on animal weight gain and grass intake per hectare implies that the area needed to produce the obtained level of weight gain and grass intake in heifers and sows was lower in the MI and AL systems compared to the systems where sows and heifers grazed alone. A positive effect on weight gain and productivity per unit of land has earlier been found in other studies with mixed and alternate grazing of other animal species (e.g. Nolan and Connolly, 1988; Fatyga, 1989; Sall et al., 1993; Dyrmundsson et al., 1996). The results in the present study were obtained in grazing systems aiming at a $5 \mathrm{~cm}$ compressed grazing sward height. This means that a higher grass intake in principle was rewarded by more grazing area, and that the results cannot be expected to be unambiguously valid in systems with a fixed area. Land is a limiting resource and it is important to optimise productivity per land unit. In this study the mean grazing area of the MI and $\mathrm{Al}$ systems was lower than the sum of the $\mathrm{HN}$ and $\mathrm{SN}$ systems only in Trial 1, whereas it was opposite in Trial 2. This should be explained by the relatively low herbage mass per hectare and possibly a higher animal productivity in the MI system in Trial 2. It is not likely that soil variation could have influenced the results significantly in this study, as the positive effects of mixed grazing was consistent between the two trials on different locations and between replicates within Trial 2. The increased animal productivity per hectare in the
MI and AL grazing systems must, therefore, be related to a better utilisation of the present herbage due to a better herbage quality, less herbage rejection and higher intake, or/and improved feed conversion in the animals. The herbage quality of the MI and AL systems was better compared with the SN system with respect to crude protein content and organic matter digestibility for pigs in both trials. The value of these parameters were only higher compared with the $\mathrm{HN}$ system in Trial 1, and lower in Trial 2. However, the herbage quality of the $\mathrm{HN}$ paddocks represents the bite grass only, and as rejected herbage counted for a significant part in this system, the average quality in a given area would have been a little lower than the given numbers for bite grass. The proportion of rejected herbage was much lower in the MI and SN systems compared with the HN system. This implies that especially the heifers in the MI and AL systems must have experienced a significantly larger area per animal with herbage acceptable for grazing and of good quality too, as the rejected herbage is generally characterised by a high proportion of stems having a relatively low digestibility (Søegaard et al., 2001). The feed conversion ratio cannot be estimated from the data obtained in these experiments, but differences in the load of gastro-intestinal nematodes in the heifers could be speculated to be a major factor in this respect, as mentioned above. In conclusion, both the herbage quality, the proportion of rejected herbage and the load of gastro-intestinal nematodes in heifers (Roepstorff et al., in preparation) could have positively influenced animal weight gain per day and hectare in the MI and AL systems in this study.

\subsection{Perspectives}

This study demonstrates a significant nutritional potential in grazing for sows, both grazing alone or in combination with heifers. Mixed grazing holds a significant potential for reduced nitrogen load per hectare compared with grazing sows alone, both due to the reduced stocking rate and due to the improved animal production. However, it is likely that the intake of herbage in sows is influenced by a number of factors such as the offer and quality of herbage, the amount of supplemented concentrates, and the ratio of heifers in the system. Thus the importance of grass/ clover for grazing by sows can be optimised by both 
improved management of the pasture and by suitable choice of supplemented concentrates. The study demonstrates that mixed grazing with sows can be beneficial for first year grazing heifers, but it has not been clarified how the effect is influenced by factors like the ratio of sows and herbage on offer. New experimental work should focus in more detail on these factors and their interactions.

\section{Conclusion}

- Mixed and alternate grazing systems increased animal weight gain and herbage intake both per individual and per hectare compared with the systems where sows and heifers grazed alone. However, the individual weight gain and herbage intake in sows were only slightly and non-significantly higher in the $\mathrm{MI}$ and $\mathrm{AL}$ systems compared with the SN system.

- The need for topping was higher in the SN system, just as the herbage had a lower feeding value.

- The differences obtained in heifer weight gain between the HN and MI/AL systems could only in part be related to sward height, herbage mass and herbage quality.

- The estimated grass intake in sows constituted from $42 \%$ to $46 \%$ of the daily net energy intake in Trial 1, and 55\% in Trial 2, which corresponds to an intake of approximately $2.0-2.5 \mathrm{~kg}$ grass/clover organic matter per sow per day.

\section{Acknowledgements}

This work was supported by the Danish Directorate for Food, Fisheries and Agri Business through The Danish Research Centre for Organic Farming (DARCOF). Thanks are due to Senior Scientist Verner Friis Kristensen, Scientist Torkil Stensig, Agricultural technicians Hanne Pedersen, Erling Olesen, Maarten van Leeuwen, and Manager Kjeld Mortensen and his staff for skilled assistance.

\section{References}

Andersen, H.R., 1996. Energibehov til kvier af kødrace. Notat fra Statens Husdyrbrugsforsøg, p. 5. In Danish.
Andersen, H.R., Kristensen, T., Bligaard, H.B., Thamsborg, S.M., 2002. Studeproduktion ved afgræsning af ferske enge. Effekt af belægningsgrad og slutfedningsstrategier på sundhed, tilvækst, foderforbrug, slagte-og kødkvalitet. DJF-rapport nr. 40 Husdyrbrug, p. 87. In Danish.

AOAC, 1990. Official Methods of Analysis, 15th edition. Association of Official Analytical Chemists International, Washington, DC.

Boisen, S., Fernandez, J.A., 1992. Ny metode til bestemmels af energiværdien $\mathrm{i}$ foderblandinger til svin. Meddelelse 825 (5 pp., in Danish).

Chroust, K., Horak, F., Zizlavsky, J., Zizlavska, S., 1998. The course and control of parasitoses of sheep and cattle in mixed grazing. Veterinarni-Medicina 43 (5), 153-159.

Close, W.H., Cole, D.J.A., 2000. Nutrition of Sows and Boars. Nottingham University Press, UK. 377 pp.

Danielsen, V., unpublished. Requirements of NE for maintenance and body weight gain in pregnant sows. In preparation.

Danielsen, V., Vestergaard, E.-M., 2001. Dietary fibre for pregnant sows: effect on performance and behaviour. Anim. Feed Sci. Technol. 90, 71-80.

Dyrmundsson, O., Jonmundsson, J.V., Richter, S.H., 1996. Grazing experiments with sheep and calves on cultivated grassland at Hvanneyri during the summers of 1975-1979. Icel. Agric. Sci. 10, 219-240.

EØF, 1971. De Europæiske Fællesskabers Tidende. Nr. L 155/13. Kommisionens første direktiv af 15. juni 1971 om fastsættelse af fællesskabsanalysemetoder til den officielle kontrol af foderstoffer (71/250/EØF), p. 430.

EU, 1999. Council Directive no. 1804/1999 of 19th July 1999. Official J. Eur. Communities 222, 1-28.

Fatyga, J., 1989. Animal production from pastures in the Sudeten mountains. Proceedings of the XVI International Grassland Congress, 4-11 October, Nice, France.

Fernández, J.A., Jørgensen, H., Just, A., 1986. Comparative digestibility experiment with growing pigs and adult sows. Anim. Prod. 43, 127-132.

Foldager, J., Sejrsen, K., Sørensen, J.T., 1988. Fodringsintensitetens indflydelse på tilvækst og foderudnyttelse hos RDM-og SDMkvier. Report no. 648 from the National Institute of Animal Science, Denmark. 121 pp., in Danish, with an English summary and subtitles.

Hansen, B., 1989. Determination of nitrogen as elementary N, an alternative to Kjeldahl. Acta Agric. Scand. 39, 113-118.

Ingvartsen, K.L., 1994. Foderoptagelse-ungdyr. Beretning nr 724 fra Statens Husdyrbrugsforsøg, p. 41. In Danish.

Jordan, H.E., Phillips, W.A., Morrison, R.D., Doyle, J.J., McKenzie, K., 1988. A 3-year study of continuous mixed grazing of cattle and sheep: parasitism of offspring. Int. J. Parasitol. 18 (6), $779-784$.

Just, A., 1982. The net energy value of balanced diets for growing pigs. Livest. Prod. Sci. 8, 541-555.

Just, A., Jørgensen, H., Fernandez, J.A., 1983. Svinenes behov for FEs til vedligehold samt foderstyrkens betydning for foderforbruget og kroppens indhold af kød. Medd. - Statens Husdyrbrugsfors. 488, 4 (in Danish).

Larsen, V.A., 2000. Sow herd management in outdoor production 
systems. Ph.D. Thesis. Danish Institute of Agricultural Sciences, Denmark, p. 108.

Mahieu, M., Aumont, G., Michaux, Y., Alexandre, G., Archimede, H., Boval, M., Theriez, M., 1997. Mixed grazing sheep/cattle on irrigated pastures in Martinique (FWI). Prod. Anim. 10 (1), $55-65$.

Nari, A., Robledo, M., Dambrauskas, G., Rizzo, E., Elizalde, M., Bugarin, J.C., 1987. Helminth control in weaned lambs on natural pasture: II. Alternate grazing with cattle in an area of crystalline basement rock. Veterinaria, Uruguay 23 (97), 15-22.

Nissen, E.T., 2000. Græsningseffekter på kløver i afgræsningssystemer med søer og eller kvier. Master-thesis, The Royal Veterinary and Agricultural University, Denmark, p. 75. In Danish with a summary in English.

Nolan, T., Connolly, J., 1988. Irish research on mixed grazing by cattle and sheep: I. 15 years of results. Fourrages 113, 57-82.

NRC, 1998. Nutrient Requirements of Swine, 10th ed. National Academy Press, Washington, DC. 189 pp.

Ogel, S., 1997. Aménagement des parcs en élevage de truies plein air. Résultats de recherche en production porcine. Chambre régionale d'agriculture, pp. 3-5.

Quintana, S., Pepe, C., Ibarburu, A., Zabala, E., Nari, A., Marmol, E., Fabregas, B., 1987. Helminth control in weaned lambs on natural pasture: I. Alternate grazing with cattle in an area of superficial basalt. Veterinaria, Uruguay 23 (97), 6-14.

Rasmussen, K.J., Nielsen, O.H., Olesen, S.E., Schjønning, P., 1995. Karakterisering af jordarealer ved Forskningscenter Bygholm. SP rapport, vol. 30.70 pp., in Danish.

Rivera Ferre, M.G., Edwards, S., Mayes, R.W., Riddoch, I., Hovell, F.D.DeB., 2001. The effect of season and level of concentrate on the voluntary intake and digestibility of herbage by outdoor sows. Anim. Sci. 72, 501-510.

Roepstorff, A., Monrad, J., Sehested, J., Nansen, P., 2000. Mixed grazing with sows and heifers-parasitological aspects. In: Hermansen, J.E., Lund, V., Thuen, E. (Eds.), Ecological Animal Husbandry in the Nordic Countries, pp. 41-44. DARCOF Report no. 2/2000.

Roepstorff, A., Monrad, J., Sehested, J., Søegaard, K., Danielsen, V., unpublished. Mixed grazing with sows and heifers: effects on gastrointestinal nematodes. In preparation.

Sall, C., Nolan, T., Connolly, J., Thiam, M.M., Diene, M., 1993. Effect of botanical pasture composition and stocking rate on nutrition and performance of cattle, sheep and goates grazing the same area. Ann. Zootechnie 42 (2), 196-197.

SAS Institute Inc., 1999. SAS Version eight, SAS OnlineDoc. SAS Institute Inc., Cary, USA.

Schwarz, H.J., Schultka, W., von Engelhardt, W., Hofmann, R.R., 1988. Evaluation of mixed grazing systems on arid pastures in the tropics: potentials and limitations of an integrated approach. Giessener Beitrage zur Entwicklungsforschung, I Symposien 17, 95-105.

Sehested, J., Breinhild, K.K., Søegaard, K., Vognsen, L., Hansen,
H.H., Fernándéz, J.A., Danielsen, V., Kristensen, V.F., 1999. Use of $n$-alkanes to estimate grass intake and digestibility in sows. In: Dove, H., Coleman, S.W. (Eds.), Nutritional Ecology of Herbivores. Satellite Symposium: Emerging Techniques for Studying the Nutrition of Free Ranging Herbivores. April 10-11 1999. San Antonio, Texas. CD-ROM.

Sehested, J., Søegaard, K., Danielsen, V., Kristensen, V.F., 2000. Mixed grazing with sows and heifers - effects on animal performance and pasture. In: Hermansen, J.E., Lund, V., Thuen, E. (Eds.), Ecological Animal Husbandry in the Nordic Countries, pp. 35-39. DARCOF Report no. 2/2000.

Søegaard, K., Sehested, J., Danielsen, V., 2000. Mixed grazing with heifers and pregnant sows. Grassld. Sci. Eur. 5, 359-361.

Søegaard, K., Lund, P., Vinther, F., Petersen, S.O., Aaes, O., 2001. Afgræsning med malkekøer. Betydning af kløveriblanding, PBV-og AAT-niveau i kraftfoder, slæt/afgræsning, ammoniakfordampning og N2-fiksering for udbytter og N-balancer. DJFrapport nr. 55, Markbrug. 103 pp., in Danish with summary in English.

Strudsholm, F., Aaes, O., Madsen, J., Kristensen, V.F., Andersen, H.R., Hvelplund, T., Østergaard, S., 1999. Danske fodernormer til kvæg. Rapport nr. 84. Landbrugets Rådgivningscenter, Landskontoret for Kvæg, 47 pp., in Danish.

Tecator, A.B., 1978. Determination of crude fibre in some feed and food samples by using the fibertec system and Weende method. Tecator AB, Box 70, S-26301 Hoganæs, Sweden. Application Note 01 .

The National Committee for Pig Breeding, Health and Production, 2002. Normer for næringsstoffer (Nutrient recommendations), 10th ed. Axelborg, Copenhagen. 4 pp.

Theil, P.K., 2002. Energy and protein metabolism in pregnant and lactating sows. Ph.D. Thesis. The Royal Veterinary and Agricultural University, DK-Copenhagen and Danish Institute of Agricultural Sciences, DK-Foulum, p. 140.

Tilley, J.M.A., Terry, A., 1963. A two stage technique for the digestion of forage crops. J. Br. Grassld. Soc. 18, 104-111.

Troxler, J., 1998. Mixed pasture with sheep and cattle. Rev. Suisse Agric. 30 (2), 53-56.

Vestergaard, E.M., Danielsen, V., Larsen, A.E., 1995. Utilization of dried grass meal by young growing pigs and sows. Abstracts of the 46th Annual Meeting EAAP, Prague, 4-7 September, p. 97.

Watson, C., Edwards, S., 1997. Outdoor pig production: what are the environmental costs? Environmental and Food Sciences Research Report. SAC, Scotland, pp. 12-14.

Weisbjerg, M.R., Hvelplund, T., 1992. Beregning af nettoenergiindhold $\left(\mathrm{FE}_{\mathrm{k}}\right)$ i kraftfoderblandinger til kvæg ud fra kemisk sammensætning samt fordøjeligheden af organisk stof. Meddelelse, vol. 813. Statens Husdyrbrugsforsøg/National Institute of Animal Science, Denmark. In Danish.

Weisbjerg, M.R., Hvelplund, T., 1993. Estimation of net energy content (FU) in feeds for cattle. Report No. 3/1993 from the National Institute of Animal Science, Denmark. 